\title{
Analysis of measurement scales of organizational commitment
}

\section{Análisis de las escalas de medición del compromiso organizacional}

\author{
VÁZQUEZ-CUJ, Luis Arturo†*, MAGAÑA-MEDINA, Deneb Elí, MAPÉN-FRANCO Fabiola de Jesús \\ and BERTTOLINI-DÍAZ, Gilda María
}

Universidad Juárez Autónoma de Tabasco. Av. Universidad S/N. Zona de la Cultura Col. Magisterial, Villahermosa, Centro, Tabasco, México. C.P. 86040.

ID $1^{\text {st }}$ Author: Luis Arturo, Vázquez-Cuj / ORC ID: 0000-0003-2613-1183

ID $2^{\text {nd }}$ Coauthor: Deneb Elí, Magaña-Medina / ORC ID: 0000-0002-8579-596X, Researcher ID Thomson: I-5521-2017

ID $3^{\text {rd }}$ Coauthor: Fabiola de Jesús, Mapén-Franco / ORC ID: 0000-0002-8436-4615, Researcher ID Thomson: S-48712018

ID $4^{\text {th }}$ Coauthor: Gilda María-Berttolini Díaz / ORC ID: 0000-0001-5889-4420, Researcher ID Thomson: N-1435-2017

DOI: $10.35429 / J L E .2019 .4 .3 .1 .8$

Received January 28, 2019; Accepted June 30, 2019

\begin{abstract}
The main objective of this study is to identify and analyze the measurement scales used to determine the organizational commitment (OC) of workers, based on an exhaustive bibliographic review in the main scientific databases. The research is of a qualitative, descriptive type of comparative nature between the different instruments used to measure the level of identification of employees with the organization, as well as reliability through internal consistency, through literary review related to the construct in study. The importance of identifying the degree of involvement of labor personnel towards the organization, as well as their classification in the dimensions that make up the organizational commitment is necessary for social research and organizations to formulate proposals focused on the contribution and strengthening of the worker-employer relationship.
\end{abstract}

\begin{abstract}
Resumen
El presente estudio tiene como objetivo principal identificar y analizar las escalas de medición que se emplean para determinar el compromiso organizacional (CO) de los trabajadores, a partir de una exhaustiva revisión bibliográfica en las principales bases de datos científicas. La investigación es de tipo cualitativa, descriptiva de corte comparativo entre los diferentes instrumentos utilizados para medir el nivel de identificación de los empleados con la organización, así como la confiabilidad a través de la consistencia interna, por medio de la revisión literaria relacionada con el constructo en estudio. La importancia de identificar el grado de involucramiento del personal laboral hacia la organización, así como su clasificación en las dimensiones que conforman el compromiso organizacional es menester de la investigación social y las organizaciones, para formular propuestas enfocadas a la contribución y fortalecimiento de la relación trabajador-empleador.
\end{abstract}

Compromiso organizacional, Escala, Confiabilidad

\footnotetext{
* Correspondence to Author (email: luisvarturo@ hotmail.com)

$\dagger$ Researcher contributing as first author.
} 


\section{Introduction}

Organizations face a great challenge in relation to the commitment of workers, which is why they have focused their efforts on knowing the level of affinity of employees towards their objectives. Various authors (Bayona Sáez, Goñi Legaz, and Madorrán García, 2000; Guevara Bedoya and Fernández Poveda, 2017; Tejada and Arias, 2005) maintain that institutions that have workers who identify with them create lasting links and a labour relationship based on loyalty prevails. As a result, production processes and organizational culture are stable (Córdova and Ochoa, 2018) and their development is preserved by avoiding and/or reducing problems of turnover and absenteeism (Patrón, 2018), which generate higher costs related to training programmes.

Organizational commitment is a theoretical construct that has been widely studied for its relationship to and prediction of the desire to leave an organization (Arciniega and González, 2006; Guevara Bedoya and Fernández, 2017; Porter, Steers, Mowday, Boulian, 1974; Tett Meyer, 1993). Given the purpose of the research, the scale by Porter, Steers, Mowday and Boulian (1974) was studied. However, this model proposes only one dimension focused on the worker's attitudes with respect to his or her work performance, and the instrument is made up of 15 items. The OCQ questionnaire was developed afterwards (Mowday, Steers and Porter, 1979). This instrument considered 15 questions with answer options on a Likert scale with seven options, with minimum value $1=$ strongly disagree and value $7=$ strongly agree .

The following model, and one of the most replicated in both the English and Spanish languages, is the one designed by (Allen and Meyer, 1990; Meyer and Allen, 1991; Meyer, Allen, and Smith, 1993), the original scale was integrated by 24 elements distributed in three dimensions: affective commitment (AC), continuity commitment (CC) y normative commitment (NC). In 1993, the original instrument of the mentioned authors was reduced to six reagents for each one of the three dimensions with a Likert-type response format that goes from $1=$ totally in disagreement to $5=$ totally in agreement and with acceptable values of internal consistency (Nunnally and Bernstein, 1994).

\section{Justification}

The relevance of the study lies in showing the instruments of greatest usability in measuring organizational commitment, as well as indicators of reliability and validity of content, (Quero, 2010; Tomás Marco, González-Romá, Gómez Benito, 2000) in research conducted in the public and private sectors. The measurement scales of the subject in question were designed in the English language, so it has been necessary to apply translation and adaptation to Spanish and the context where they have been used, based on the above interest in analyzing the similarities of context and the population participating in the studies to measure organizational commitment.

\section{Problem}

The importance of identifying the level and type of commitment of the labor force in organizations is increasingly in the interest of managers, as a preventive measure to avoid staff turnover and decreased productivity, for this reason it is necessary to identify the scales of greatest reference as well as indicators of reliability and validity, a factor to consider are the similarities of population and language, as this will serve as the basis for replicating a study in the population to be evaluated.

\section{Objectives}

\section{General Objective}

To identify the scales for measuring organizational commitment to greater usability as well as its values of reliability and validity.

\section{Specific Objectives}

- To identify the most commonly used scales in organizational commitment measurement studies and determine the values of reliability and validity.

\section{Theoretical Framework}

The main studies on OC as well as the designers of the most replicated scales define this construct as the degree of identification and participation of a worker towards his or her employing organization (Porter et al., 1974), in addition to considering aspects such as the involvement and acceptance of company goals and values, extra effort and a feeling of pride and belonging. 
Some authors (Becker, 1960; Buchanan, 1974; Mowday et al., 1979) considered this construct to be one-dimensional. In table 1 , some of the definitions of the main authors related to the topic are detailed:

\begin{tabular}{|c|c|}
\hline Author & Definition \\
\hline (Becker, 1960) & $\begin{array}{l}\text { It is the emotional bond that } \\
\text { the worker establishes with } \\
\text { the organization }\end{array}$ \\
\hline $\begin{array}{l}\text { (Porter, Steers, Mowday } \\
\text { and Boulian, 1974) }\end{array}$ & $\begin{array}{l}\text { Affinity and identification of } \\
\text { an individual with a certain } \\
\text { organization }\end{array}$ \\
\hline $\begin{array}{l}\text { (O 'Reilly and Chatman, } \\
1986)\end{array}$ & $\begin{array}{l}\text { It is the link between a } \\
\text { person and an organization }\end{array}$ \\
\hline (Meyer and Allen, 1991) & $\begin{array}{l}\text { It is the relationship between } \\
\text { the worker and their } \\
\text { company based on } \\
\text { emotional perceptions }\end{array}$ \\
\hline (Buchanan, 1974) & $\begin{array}{l}\text { It is the effective-emotional } \\
\text { attachment of the worker to } \\
\text { the goals and policies of } \\
\text { their organization }\end{array}$ \\
\hline $\begin{array}{l}\text { (Mowday, Porter and } \\
\text { Steers, 1982) }\end{array}$ & $\begin{array}{l}\text { It is the strong desire to } \\
\text { remain in the organization } \\
\text { and the achievement of its } \\
\text { objectives }\end{array}$ \\
\hline
\end{tabular}

Table 1 Organizational Commitment Definitions Source: prepared by the authors

However, in subsequent studies, the instruments had three dimensions (Allen and Meyer, 1990; Herscovitch and Meyer, 2002; Meyer and Allen, 1984, 1991). In such a way, they point out that the normative commitment that has its bases in the institutional reciprocity; the commitment of continuity is related to the costs of leaving the organization and finally the affective commitment; this is achieved when the individual needs are covered and the expectations of the workers are reached, this model is known as the Meyer and Allen model. (see figure 1).

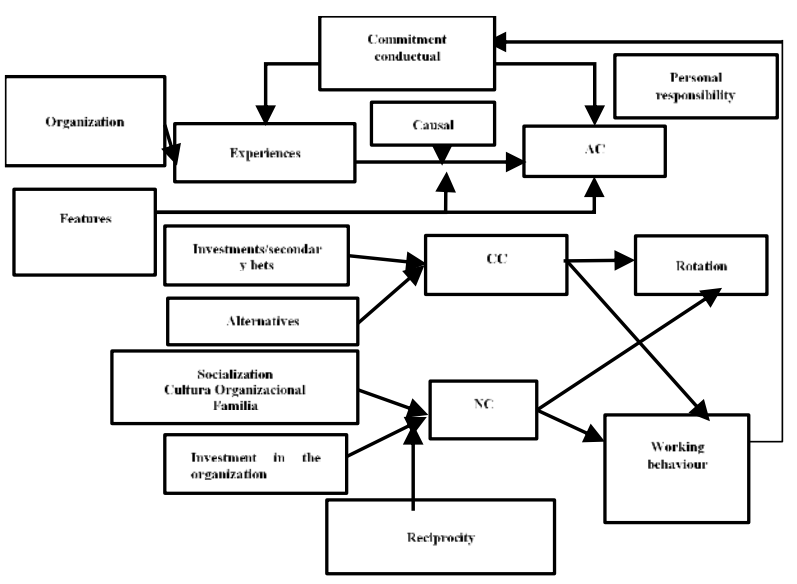

Figure 1 Three-factor model of organizational commitment

Source: Taken from Meyer and Allen, 1991 P.p 68
- Affective Commitment: It is the adherence of the individual to a certain organization, establishing strong ties, which in turn directly impacts the participation and emotional involvement shown by the individual towards his or her organization (Meyer and Allen, 1991).

- Commitment to Continuity: also known as calculative, it is a feeling of need to continue in the organization based on the time invested and the lack of opportunities abroad, it is possible to say that there is a state of dependency linked to the economic cost that could force the individual to continue in the organization (Meyer and Allen, 1991).

- Normative commitment: it is the relationship of the individual towards the organization which is based on feelings of gratitude, sometimes derived from incentives and rewards, in certain cases individuals feel special gratitude towards the company for having given them the opportunity to belong to it (Meyer \& Allen, 1991). Arciniega and González (2006) establish this relationship with emotional aspects, such as loyalty to the organization, sense of belonging and gratitude for the granted opportunities.

\section{Research Methodology}

The research is of a descriptive type since it pursues the analysis and description of the scales of measurement of organizational commitment (Hernández, Fernández and Baptista, 2014) with the aim of showing the main characteristics of the population and the indices of reliability and validity. The study entails a non-experimental transversal design, which consisted of an exhaustive documentary review in the main databases, having as a premise the articles in the Spanish language, to analyze the results derived from the scale used, as well as its translation and adaptation to the application context. The sources used for the project were based on:

- Specialized databases such as Redalyc (Network of Scientific Journals of Latin America and the Caribbean, Spain and Portugal).

\section{- Scopus.}

- Web of Science. 
June, 2019 Vol.3 No.4 1-8

\section{Results}

According to the results obtained through the literature review, the classification of the studies developed in Spanish-speaking contexts was conducted with the aim of studying the type and number of population, the number of reagents used, and the level of reliability and validity. In table 2, eight studies selected based on the criteria mentioned in the previous paragraph are presented.

\begin{tabular}{|c|c|c|c|c|}
\hline No & Author & Instrument & $\boldsymbol{\alpha}$ & Observations \\
\hline 1 & $\begin{array}{l}\text { (Fonseca, } \\
\text { Cruz and } \\
\text { Chacón, } \\
\text { 2019) }\end{array}$ & $\begin{array}{l}\text { Author's } \\
\text { design } \\
\text { Likert scale } \\
\text { with 5 } \\
\text { answers } \\
\text { ranging } \\
\text { from } 1 \\
\text { (strongly } \\
\text { disagree) to } \\
5 \text { (strongly } \\
\text { agree) } \\
\end{array}$ & .86 to .89 & $\begin{array}{l}\text { Confirmatory } \\
\text { factor analysis } \\
\text { with } \\
\text { acceptable } \\
\text { adjustment } \\
\text { measures was } \\
\text { performed }\end{array}$ \\
\hline 2 & $\begin{array}{l}\text { (Baez- } \\
\text { Santana, } \\
\text { Zayas- } \\
\text { Agüero, } \\
\text { Velázquez- } \\
\text { Zaldívar } \\
\text { and Lao- } \\
\text { León, } \\
\text { 2019) }\end{array}$ & $\begin{array}{l}\text { (Meyer, } \\
\text { Allen and } \\
\text { Smith, } \\
\text { 1993) } \\
\text { Likert scale } \\
\text { with 5 } \\
\text { answers } \\
\text { ranging } \\
\text { from 1 } \\
\text { (strongly } \\
\text { disagree) to } \\
5 \text { (strongly } \\
\text { agree) }\end{array}$ & $\begin{array}{l}\mathrm{AC}=.83 \\
\mathrm{CC}=.96 \\
\mathrm{NC}=.92\end{array}$ & $\begin{array}{l}\text { Degree of } \\
\text { identification, } \\
\text { organizational } \\
\text { commitment, } \\
\text { and adherence } \\
\text { to the three- } \\
\text { factor OC } \\
\text { Three factors } \\
\text { with } 75 \% \text { of } \\
\text { total variance }\end{array}$ \\
\hline$\underline{3}$ & $\begin{array}{l}\text { (Morales } \\
\text { Cardenas, } \\
\text { Perez } \\
\text { Sanchez, \& } \\
\text { Haidar } \\
\text { Torres, } \\
\text { 2018) }\end{array}$ & $\begin{array}{l}\text { (Allen and } \\
\text { Meyer, } \\
1990 \text { ) } \\
\text { Likert scale } \\
\text { with } 5 \\
\text { answers } \\
\text { ranging } \\
\text { from 1 } \\
\text { (strongly } \\
\text { disagree) to } \\
5 \text { (strongly } \\
\text { agree) }\end{array}$ & .91 & $\begin{array}{l}\text { Organizational } \\
\text { Commitment } \\
\text { has a positive } \\
\text { relationship } \\
\text { with Perceived } \\
\text { Organizational } \\
\text { Support and } \\
\text { Ethical } \\
\text { Climate }\end{array}$ \\
\hline$\underline{4}$ & $\begin{array}{l}\text { (Zayas } \\
\text { Agüero and } \\
\text { Báez } \\
\text { Santana, } \\
\text { 2016) }\end{array}$ & $\begin{array}{l}\text { (Meyer and } \\
\text { Allen, } \\
1991 \text { ) } \\
\text { Likert scale } \\
\text { with 5 } \\
\text { answers } \\
\text { ranging } \\
\text { from 1 } \\
\text { (strongly } \\
\text { disagree) to } \\
5 \text { (strongly } \\
\text { agree) }\end{array}$ & .70 & $\begin{array}{l}\text { Expert } \\
\text { validity, pilot } \\
\text { test, } 79 \% \\
\text { medium OC } \\
\text { level and } 19 \% \\
\text { high OC level }\end{array}$ \\
\hline No & Author & Instrument & $\alpha$ & Observations \\
\hline 5 & $\begin{array}{l}\text { (Böhrt, } \\
\text { Romero } \\
\text { and Díaz } \\
\text { Bretones, } \\
\text { 2014) }\end{array}$ & $\begin{array}{l}\text { (Meyer and } \\
\text { Allen, } \\
1997 \text { ) } \\
\text { Likert scale } \\
\text { with } 7 \\
\text { answers } \\
\text { ranging } \\
\text { from 1 } \\
\text { (strongly } \\
\text { disagree) to } \\
7 \text { (strongly } \\
\text { agree) }\end{array}$ & & $\begin{array}{l}\text { The study } \\
\text { divided the } \\
\text { population into } \\
\text { three segments: } \\
\text { services, } \\
\text { workers and } \\
\text { office workers, } \\
\text { in which tests } \\
\text { were carried out } \\
\text { on the } \\
\text { perception of } \\
\text { AC, CC and } \\
\text { NC, obtaining } \\
\text { different results } \\
\text { in each } \\
\text { segment. }\end{array}$ \\
\hline
\end{tabular}

\begin{tabular}{|c|c|c|c|c|}
\hline 6 & $\begin{array}{l}\text { (Ríos, } \\
\text { Téllez and } \\
\text { Ferrer, } \\
2010)\end{array}$ & $\begin{array}{l}\text { (Meyer and } \\
\text { Allen, } \\
\text { 1997) } \\
\text { Likert scale } \\
\text { with } 7 \\
\text { answers } \\
\text { ranging } \\
\text { from } 1 \\
\text { (strongly } \\
\text { disagree) to } \\
6 \text { (strongly } \\
\text { agree) }\end{array}$ & $\begin{array}{l}\mathrm{AC}=.85 \\
\mathrm{CC}=.91 \\
\mathrm{NC}=.82\end{array}$ & $\begin{array}{l}\text { Empowerment } \\
\text { predicts } \\
\text { organizational } \\
\text { commitment, } \\
\text { the reliability } \\
\text { of the three } \\
\text { dimensions of } \\
\text { OC }\end{array}$ \\
\hline 7 & $\begin{array}{l}\text { (Ramos, } \\
\text { Martínez } \\
\text { and } \\
\text { Maldonado, } \\
\text { 2009) }\end{array}$ & $\begin{array}{l}\text { (Allen and } \\
\text { Meyer, } \\
\text { 1990) } \\
\text { Likert scale } \\
\text { with } 7 \\
\text { answers } \\
\text { ranging } \\
\text { from 1 } \\
\text { (strongly } \\
\text { disagree) to } \\
7 \text { (strongly } \\
\text { agree) }\end{array}$ & $\begin{array}{l}\mathrm{AC}=.76 \\
\mathrm{CC}=.72 \\
\mathrm{NC}=.73\end{array}$ & $\begin{array}{l}\text { Confirmatory } \\
\text { factor analysis } \\
\text { with } \\
\text { acceptable } \\
\text { adjustment } \\
\text { values was } \\
\text { performed, it } \\
\text { was found that } \\
\text { OC with high } \\
\text { values } \\
\text { provides a } \\
\text { positive } \\
\text { relationship in } \\
\text { personnel } \\
\text { behavior }\end{array}$ \\
\hline 8 & $\begin{array}{l}\text { (Betanzos } \\
\text { and Paz, } \\
2007)\end{array}$ & $\begin{array}{l}\text { Design of } \\
\text { the authors } \\
\text { based on } \\
\text { the } \\
\text { literature } \\
\text { related to } \\
\text { the topic. } \\
\text { (OCQ, } \\
\text { Meyer and } \\
\text { Allen and } \\
\text { Lodahl and } \\
\text { Kejner) } \\
\text { Response } \\
\text { format } \\
\text { determined } \\
\text { for each } \\
\text { dimension }\end{array}$ & $\begin{array}{l}\mathrm{AC}=.87 \\
\text { Implication= } \\
.84 \\
\mathrm{CC}=.76\end{array}$ & $\begin{array}{l}\text { The scale was } \\
\text { reconfigured } \\
\text { based on } \\
\text { expert validity, } \\
\text { the CC } \\
\text { dimension was } \\
\text { evaluated } \\
\text { independently } \\
\text { by the } \\
\text { characteristic } \\
\text { of the items. }\end{array}$ \\
\hline 9 & $\begin{array}{l}\text { (Betanzos, } \\
\text { Andrade y } \\
\text { Paz, 2006) }\end{array}$ & $\begin{array}{l}\text { (Meyer et } \\
\text { al., 1993; } \\
\text { Mowday et } \\
\text { al., 1982) } \\
\text { Likert scale } \\
\text { with } 5 \\
\text { answers } \\
\text { ranging } \\
\text { from 1 } \\
\text { (strongly } \\
\text { disagree) to } \\
5 \text { (strongly } \\
\text { agree) }\end{array}$ & $\begin{array}{l}\text { Scale } 1 \\
\mathrm{AC}=.81 \\
\mathrm{CC}=.48 \\
\mathrm{NC}=.82 \\
\text { Scale } 2=.87\end{array}$ & $\begin{array}{l}\text { The OCQ } \\
\text { instrument } \\
\text { yields two } \\
\text { factors, } \\
\text { contrasting the } \\
\text { one- } \\
\text { dimensional } \\
\text { theory. The } \\
\text { Meyer and } \\
\text { Allen scale } \\
\text { gives five } \\
\text { factors and the } \\
\text { theory } \\
\text { mentions } \\
\text { three. } \\
\text { Unifying the } \\
\text { two } \\
\text { instruments, } \\
\text { the factor } \\
\text { analysis yields } \\
\text { four factors } \\
\text { with } \alpha=.87\end{array}$ \\
\hline
\end{tabular}

Table 2 Scales for measuring organizational commitment in Latin America

Source: own design based on data from the authors cited.

Continuing with the description of the information obtained, table 3 details the complements to table 2 , which mentions the number of reagents used in each of the studies, as well as the type of population, public or private sector and the size of the sample. 
Thus, it was determined that the scale of greatest reference in the studies carried out in Latin America was the one designed by (Allen and Meyer, 1990; Allen and Meyer, 1996; Meyer and Allen, 1991; Meyer et al., 1993; Meyer, Stanley, Herscovitch, Topolnytsky, 2002), in which the multi-dimensionality of the aforementioned scale is considered; affective commitment, continuity commitment and normative commitment. Similarly, a study using the OCQ tool can be observed, combining items with the Meyer and Allen scale. Of the aspects that stand out, we found acceptable reliability values above .70 (Nunnally and Bernstein, 1994), as well as the lower levels in this index for the continuity commitment dimension (see table 2). Similarly, it is important to consider the wording of the elements of the continuity commitment factor (Zayas Agüero and Báez Santana, 2016) since by their nature they are written in a negative or inverse way, so special attention is recommended when analyzing the results. (see table 3 )

\begin{tabular}{|c|c|c|c|}
\hline No. & Items used & Population Type & Sample \\
\hline 1 & $\begin{array}{l}\text { Case } 3 . \\
25 \text { items and four } \\
\text { factors }\end{array}$ & $\begin{array}{l}\text { Teachers and } \\
\text { administrative } \\
\text { staff of a public } \\
\text { university }\end{array}$ & 230 \\
\hline 2 & $\begin{array}{l}18 \\
\text { translated items } \\
\text { adapted to and } \\
\text { Cuban context. }\end{array}$ & $\begin{array}{l}\text { Production and } \\
\text { marketing sector } \\
\text { employees }\end{array}$ & 603 \\
\hline$\underline{3}$ & $\begin{array}{l}18 \\
\begin{array}{l}\text { items } \\
\text { translated and } \\
\text { adapted to the } \\
\text { context }\end{array}\end{array}$ & Public servers & $\underline{250}$ \\
\hline$\underline{4}$ & $\begin{array}{lr}18 & \text { items } \\
\text { translated } & \text { and } \\
\text { adapted to a } \\
\text { Cuban context. } \\
\text { Six items written } \\
\text { in a negative way. }\end{array}$ & $\begin{array}{l}\text { Cuban private } \\
\text { sector employees }\end{array}$ & 92 \\
\hline 5 & $\begin{array}{l}27 \text { items } \\
\text { translated and } \\
\text { adapted to a } \\
\text { Bolivian context }\end{array}$ & $\begin{array}{l}\text { Employees from } \\
\text { the } \\
\text { manufacturing, } \\
\text { customer service } \\
\text { and hotel sectors }\end{array}$ & 424 \\
\hline 6 & $\begin{array}{l}18 \text { items on the } \\
\text { scale by Meyer et } \\
\text { al, } 1997, \\
\text { translated and } \\
\text { adapted to the } \\
\text { Mexican context }\end{array}$ & $\begin{array}{lr}\text { Private } & \text { sector } \\
\text { staff, } & \text { trade, } \\
\text { industry } & \text { and } \\
\text { service } & \end{array}$ & 147 \\
\hline 7 & $\begin{array}{l}18 \text { items on the } \\
\text { scale by Meyer et } \\
\text { al, } 1990, \\
\text { translated and } \\
\text { adapted to the } \\
\text { cultural context of } \\
\text { Mexico }\end{array}$ & $\begin{array}{l}\text { Professors of a } \\
\text { public university } \\
\text { in Mexico }\end{array}$ & 300 \\
\hline
\end{tabular}

\begin{tabular}{|l|l|l|l|}
\hline 8 & $\begin{array}{l}\text { 41 Items: } \\
\text { Involvement (16 } \\
\text { items) } \\
\text { Emotional } \\
\text { engagement (15 } \\
\text { items) } \\
\text { Continuity } \\
\text { commitment (10 } \\
\text { items) }\end{array}$ & $\begin{array}{l}\text { Private sector } \\
\text { employees } \\
\text { telecommunicatio } \\
\text { ns }\end{array}$ & 369 \\
98 & $\begin{array}{l}18 \text { items on the } \\
\text { scale by Meyer et } \\
\text { al, 1993 (scale 1) } \\
\text { and 9 items on the } \\
\text { scale by Porter et } \\
\text { al, 1982 (scale 2) }\end{array}$ & $\begin{array}{l}\text { Administrative } \\
\text { staff of an airport } \\
\text { and } \\
\text { administrative } \\
\text { staff of a } \\
\text { marketing } \\
\text { company }\end{array}$ & 233 \\
\hline
\end{tabular}

Table 3 Description of content of scales to measure Organizational Commitment and the context of application

Source: own design based on data from authors

The importance of expert analysis and judgment (Escobar-Pérez and Cuervo-Martínez, 2008) should be noted, which was considered in the present study, since it is a technique that contributes to provide solidity to measurement instruments, ensuring their understanding and contextual adaptation together with reliability, considered as the absence of errors in measurement processes (Quero, 2010). The reliability and validity of measurement instruments is important for understanding and adapting to different environments (Moreno, Herrera and Gargurevich, 2019), so that a scale can be applied to both workers in the manufacturing sector and teachers in the public sector.

\section{Conclusions}

The results presented in the study are the yield of an exhaustive analysis of research implemented in Latin America, with the aim of identifying the most widely used instruments for measuring OC. Meller and Allen's multidimensional model and the OCQ (Mowday et al., 1979), a questionnaire for measuring organizational commitment, were identified as the most widely replicated. The characteristics of the population are undoubtedly a determining factor for the success of the research; however, it was determined that, with the support of experts in the field, as well as the application of pilots and precise reviews, positive results are obtained. Areas of opportunity were detected such as the scarcity of studies in Spanish, based on confirmatory analysis and structural equation models, which enables contributions in this regard. 


\section{References}

Allen, N. J., \& Meyer, J. P. (1990). The measurement and antecedents of affective, continuance and normative commitment to the organization. Journal of Occupational Psychology, $\quad$ 63(1), 1-18. https://doi.org/10.1111/j.20448325.1990.tb00506.x

Allen, N., \& Meyer, J. P. (1996). Affective , Continuance, and Normative Commitment to the Organization: An Examination of Construct Validity. Journal of Vocational Behavior, 276(49), 252-276. https://doi.org/10.1006/jvbe.1996.0043

Arciniega, L. M., \& González, L. (2006). What is the influence of work values relative to other variables in the development of organizational commitment? ¿ Cuál es la influencia de los valores hacia el trabajo en relación con otras variables en el desarrollo del compromiso organizacional? Res. Revista de Psicología Social, 21(52), 35-50.

Baez-Santana, R. A., Zayas-Agüero, P. M., Velázquez-Zaldívar, R., \& Lao-León, Y. O. (2019). Modelo conceptual del compromiso organizacional en empresas cubanas. Ingeniería Industrial, 40(1), 14-23.

Bayona Sáez, C., Goñi Legaz, S., \& Madorrán García, C. (2000). Compromiso organizacional: implicaciones para la gestión estratégica de los recursos humanos. Revista europea de dirección y economía de la empresa, 9(1), 139-149.

Becker, H. S. (1960). Notes on the concept of Commitment. The American Journal of Sociology, $\quad 66(1), \quad 32-40$. https://doi.org/10.1086/222820

Betanzos, N., Andrade, P., \& Paz, F. (2006). Compromiso organizacional en una muestra de trabajadores mexicanos: Revista de Psicología del Trabajo y de las Organizaciones, 22(1), 25$43 . \quad$ Retrieved from http://www.redalyc.org/articulo.oa?id=2313170 45002\%0ACómo
Betanzos, N., \& Paz, F. (2007). Análisis psicométrico del compromiso organizacional como variable actitudinal. Anales de Psicología, 23(2), 207-215. Retrieved from http://www.redalyc.org/articulo.oa?id=1672320 5

Böhrt, R., Romero, C., \& Díaz Bretones, F. (2014). El compromiso organizacional entre obreros: un estudio en cuatro organizaciones bolivianas. Аjayu, 12(2), 227-245. Retrieved from

http://www.redalyc.org/pdf/1815/18154557900 4.pdf

Buchanan, B. I. (1974). Building Organizational Commitment: The Socialization of Managers in Work Organizations. Administrative Science Quarterly, 19(4), 533-546. https://doi.org/10.2307/2391809

Córdova, G. M., \& Ochoa, E. (2018). Premisas sociales del personal y las practicas organizacionales. Creencias del personal y la cultura organizacional. European Public \& Social Innovation Review, 3(2), 58-63.

Escobar-Pérez, J., \& Cuervo-Martínez, Á. (2008). Validez de contenido y juicio de expertos: Una aproximación a su Utilización. Avances en Medición, 6(1), 27-36.

Fonseca, J., Cruz, C., \& Chacón, L. (2019). Validación del instrumento de compromiso organizacional en México: evidencias de validez de constructo, criterio y confiabilidad. Revista de Psicología, 37(1), 7-29. https://doi.org/10.18800/psico.201901.001

Guevara Bedoya, L. M., \& Fernández Poveda, L. F. (2017). Work engagement y compromiso laboral: ¿Es la edad un factor diferenciador? Revista Interamericana de Psicología Ocupacional, 34(2), 108-119. https://doi.org/10.21772/ripo.v34n2a04

Hernández, R., Fernández, C., \& Baptista, P. (2014). Metodología de la investigación. Journal of Chemical Information and Modeling (Vol. 53). https://doi.org/10.1017/CBO9781107415324.00 4 
Herscovitch, L., \& Meyer, J. P. (2002). Commitment to organizational change: Extension of a three-component model. Journal of Applied Psychology, 87(3), 474-487. https://doi.org/10.1037/0021-9010.87.3.474

Kerlinger, F., \& Lee, H. (2002). Investigacion del comportamiento. México, D.F.

metodosmultivariantes_borrador.pdf. (s/f).

Meyer, J. P., \& Allen, N. J. (1984). Testing the "side-bet theory" of organizational commitment: Some methodological considerations. Journal of Applied Psychology, 69(3), 372-378. https://doi.org/10.1037/0021-9010.69.3.372

Meyer, J. P., \& Allen, N. J. (1991). A ThreeComponent Model Conceptualization of Organizational Commitment. Human Resource Management Review, 1(1), 61-89. https://doi.org/10.1016/1053-4822(91)90011-Z

Meyer, J. P., \& Allen, N. J. (1997). Commitment in the Work Place. (T. Oaks, Ed.). Califonia: SAGE Publications.

Meyer, J. P., Allen, N. J., \& Smith, C. A. (1993). Commitment to organizations and occupations: Extension and test of a three-component conceptualization. Journal of Applied Psychology, 78(4), 538-551. https://doi.org/10.1037/0021-9010.78.4.538

Meyer, J. P., Stanley, D. J., Herscovitch, L., \& Topolnytsky, L. (2002). Affective, Continuance , and Normative Commitment to the Organization : A Meta-analysis of Antecedents, Correlates, and Consequences. Journal of Vocational Behavior, 52, 20-52. https://doi.org/10.1006/jvbe.2001.1842

Morales Cardenas, T. F., Perez Sanchez, A., \& Haidar Torres, E. (2018). Apoyo Organizacional Percibido y Compromiso Organizacional, su relación con el Clima Ético de las Entidades De Fiscalización Superior. Hitos de Ciencias Económico Administrativas, 24(70), 1-15.

Moreno, J., Herrera, D., \& Gargurevich, R. (2019). Propiedades Psicométricas de la Versión en Español de la Escala de Supervisión Abusiva en Población Laboral Ecuatoriana. Revista Iberoamericana de Diagnostico y Evaluacion Psicologica, 51(2), 117-133. https://doi.org/10.21865/RIDEP51.2.09
Mowday, R. T., Porter, L. W., \& Steers, R. M. (1982). Employee-Organization Linkages: The psychology of commmitment, absenteeism, and turnover. New York: Academic Press.

Mowday, R. T., Steers, R. M., \& Porter, L. W. (1979). The measurement of organizational commitment. J Vocat Behav, 14(2), 224-247. https://doi.org/10.1016/0001-8791(79)90072-1

Nunnally, J. C., \& Bernstein, I. H. (1994). Psychometric Theory (3rd ed.). New York: McGraw-Hill.

O 'Reilly, C., \& Chatman, J. (1986). Organizational Commitment and Psychological Attachment: The Effects of Compliance, Identification, and Internalization on Prosocial Behavior. Journal of Applied Psychology, 71(3), 492-499. 9010.71 .3 .492

Patrón Cortés, R. (2018). Revista de Formación de Recursos Humanos Compromiso organizacional de una empresa maquiladora ubicada en el Sureste de México Organizational commitment of a maquila company located in Southeast of Mexico Revista de Formación de Recursos Humanos, 4(14), 15-24.

Porter, L. W., Steers, R. M., Mowday, R. T., \& Boulian, P. V. (1974). Organizational commitment, job satisfaction, and turnover among psychiatric technicians. Journal of Applied Psychology, 59(5), 603-609. https://doi.org/10.1037/h0037335

Quero, Milton, E. (2010). Confiabilidad y coeficiente Alpha de Cronbach. Telos, 12(2), 248-252.

Ramos, A., Martínez, M., \& Maldonado, G. (2009). El impacto del compromiso organizacional en la orientación al mercado. Investigación y Ciencia, 17(44), 48-55.

Ríos, M., Téllez, M. del R., \& Ferrer, J. (2010). El empowerment como predictor del compromiso organizacional en las Pymes. Contaduría y Administración, 1(231), 103-125. 
Tejada, J. M., \& Arias, F. (2005). Prácticas organizacionales y el compromiso de los trabajadores hacia la organización. Enseñanza e Investigación en Psicología, 10(2), 295-309. Retrieved from http://www.redalyc.org/html/292/29210206/

Tett, R. P., \& Meyer, J. P. (1993). Job satisfaction, organizational commitment, turnover intention, and turnover: path analyses based on meta-analytic findings. Personnel Psychology, 46(2), 259-293. https://doi.org/10.1111/j.17446570.1993.tb00874.x

Tomás Marco, I., González-Romá, V., \& Gómez Benito, J. (2000). Teoría de respuesta al ítem y análisis factorial confirmatorio: Dos métodos para analizar la equivalencia psicométrica en la traducción de cuestionarios. Psicothema, 12(2), 540-544.

Zayas Agüero, P. M., \& Báez Santana, R. A. (2016). Evaluación del compromiso organizacional en una distribuidora mayorista / Evaluation of organizational commitment in a wholesale distributor. Ciencias Holguín, Revista trimestral, 22(2). Retrieved from http://www.redalyc.org/pdf/1815/18154557900 4.pdf 